\title{
Virucidal Effect of Guggulsterone Isolated from Commiphora gileadensis
}

\author{
Authors \\ Lamjed Bouslama ${ }^{1}$, Bochra Kouidhi ${ }^{2}$, Yasir Mohammed Alqurashi ${ }^{2}$, Kamel Chaieb $^{3,4}$, Adele Papetti $^{5}$
}

\section{Affiliations}

1 Laboratory of Bioactive Substances, Center of Biotechnology of Borj Cedria, University of Tunis El Manar, Tunisia

2 Medical Laboratory Department, College of Applied Medical Sciences, Yanbu, Taibah University, Saudi Arabia

3 Department of Biochemistry, Faculty of Science, King Abdulaziz University, Jeddah, Saudi Arabia

4 Laboratory of Analysis, Treatment and valorization of Pollutants of the Environment and Products, Faculty of Pharmacy, Monastir University, Tunisia

5 Nutraceutical \& Food Chemical-Toxicological Analysis Laboratory, Department of Drug Sciences, University of Pavia, Italy

\section{Key words}

Burseraceae, Commiphora gileadensis, cytotoxicity, herpes simplex virus type 2 , respiratory syncytial virus type $B$, virucidal activity, guggulsterone

$$
\begin{array}{ll}
\text { received } & \text { May 22, } 2019 \\
\text { revised } & \text { September 12, } 2019 \\
\text { accepted } & \text { September 12, } 2019
\end{array}
$$

\section{Bibliography}

DOI https://doi.org/10.1055/a-1014-3303

Published online October 7, 2019 | Planta Med 2019; 85:

1225-1232 @ Georg Thieme Verlag KG Stuttgart · New York | ISSN 0032-0943

\section{Correspondence}

Bochra Kouidhi, PhD

Medical Laboratory Technology Department, Faculty of

Applied Medical Science, Yanbu, Taibah University

Omar Ibn Alkhattab, 46526 Yanbu, Saudi Arabia

Phone: + 966562012084 , Fax: + 966562012084

bochrak@yahoo.fr

\section{ABSTRACT}

Commiphora gileadensis, locally known as becham, is a plant used in traditional Arabian medicine for treating headache, constipation, stomach, joint pain, and inflammatory disorders. Several studies have reported its antibacterial properties; however, no study has demonstrated its antiviral activity. This study aimed to evaluate the antiviral activity of $C$. gileadensis as well as to isolate its active compound and investigate its mode of action. This activity was evaluated using 4 viruses, herpes simplex virus type 2 (HSV-2), respiratory syncytial virus type B (RSV-B), coxsackie virus B type 3 , and adenovirus type 5 by performing the plaque reduction assay and the 3-(4,5-Dimethylthiazol-2-yl)-2,5-diphenyltetrazolium bromide assays for enveloped and nonenveloped viruses, respectively. The methanol extract of $C$. gileadensis leaves only showed antiviral activity against enveloped viruses with a selectivity index of 11.19 and 10.25 for HSV-2 and RSV-B, respectively. The study of the mechanism underlying antiviral activity demonstrated a virucidal effect by direct contact with these target viruses. The active compound, isolated using bio-guided assays involving TLC, was identified as guggulsterone by HPLC-diode array detection coupled with electrospray ionization mass spectrometry. Guggulsterone is an antagonist of the bile acid receptor and a modulator of cholesterol metabolism; however, its antimicrobial properties have been reported for the first time in this study.

\section{Introduction}

Six species of the genus Commiphora grow in Saudi Arabia, especially in the west and southwest regions [1]. Commiphora gileadensis (L.) C.Chr (syn: Commiphora opobalsamum [L.] Engl.), generally referred to as "balsam of Mecca" [2], belongs to the family Burseraceae. It is widely found in the Mediterranean Basin, in areas around the Red Sea, particularly on the borders of Saudi Arabia,
Yemen, Oman, and Eritrea [3]. C. gileadensis locally known as ood-e-balsan, bechan, or balessan, is a small, thorny, medicinal tree that widely grows in Mecca region of Saudi Arabia. Bechan is a large, strong-smelling green shrub that grows to 10-12 feet [4]. On damage to the bark, it produces an oleo-gum resin, which is fragrant. The plant is famous for producing this valuable fragrant resin, as well as for its medicinal properties [5]. In traditional Arabian medicine, $C$. gileadensis extracts are used to treat headache, 


$\begin{array}{ll}\text { ABBREVIATIONS } & \\ \text { ADV-5 } & \text { adenovirus type } 5 \\ \text { CC }_{50} & 50 \% \text { cytotoxic concentration } \\ \text { CVB-3 } & \text { coxsackievirus B type } 3 \\ \text { HEp-2 } & \text { human epithelial type } 2 \\ \text { HPLC-DAD-ESI-MS/MS } & \text { HPLC-diode array detection coupled } \\ & \text { with electrospray ionization mass } \\ & \text { spectrometry } \\ \text { HSV-2 } & \text { herpes simplex virus type 2 } \\ \text { IC } & 50 \% \text { inhibitory concentration } \\ \text { NF-KB } & \text { nuclear factor kappa-light-chain- } \\ & \text { enhancer of activated B cells } \\ \text { Rf } & \text { retention factor } \\ \text { RSV-B } & \text { respiratory syncytial virus type B } \\ \text { SI } & \text { selectivity index } \\ \text { SIv } & \text { virucidal selectivity index } \\ \text { VC } 50 & \text { 50\% virucidal concentration } \\ \text { Vero } & \text { African green monkey kidney } \\ & \\ & \end{array}$

urinary retention, jaundice, constipation [6], stomach, and liver diseases, joint pain, and inflammatory disorders [7]. Conversely, the phytochemical screening of the aerial parts of this plant revealed the presence of flavonoids, sterols, triterpenes, saponins, volatile bases, and oils [8]. The plant's aqueous extract was shown to have hypotensive effects [9] and protective effects on the gastric mucosa of rats [10]. In addition, its ethanol extract demonstrated a hepatoprotective effect and strongly induced apoptosis in immortalized and transformed human epidermal cell lines [11]. Reportedly, members of the genus Commiphora exhibit antibacterial activity. For example, the ethyl acetate extract of Commiphora molmol Engl. demonstrated moderate activity against Staphylococcus aureus, Pseudomonas aeruginosa, and Plasmodium falciparum [12], and the essential oil obtained from this plant exhibited high activity against both methicillin- and gentamicin-resistant S. aureus strains [13] and biofilm formation [14]. Furthermore, the methanol extracts of $C$. gileadensis rhizomes have good activity against staphylococci and streptococci [15].

Currently, to the best of our knowledge, there are no studies assessing the antiviral activities of $C$. gileadensis. Therefore, this study aimed to evaluate the antiviral activity of this plant as well as to isolate its active compound and determine its mode of action. The study was conducted on 4 viruses that are the causative agents of several human pathologies: HSV-2, which causes genital ulcers; CVB-3, which causes several conditions such as pleurodynia, myocarditis, pericarditis, and insulin-dependent diabetes; RSV-B, which causes respiratory diseases, such as runny nose, cough, and sore throat; and ADV-5, which causes conjunctivitis and upper respiratory tract infections, such as pharyngitis, laryngitis, and sinusitis.

\section{Results}

A total of $1.66 \mathrm{~g}$ of methanol extract was obtained from $5 \mathrm{~g}$ of dried leaves. After liquid-liquid separation, the weight of hexane, dichloromethane, and methanol fractions was 370, 138, and $926 \mathrm{mg}$, respectively.

The cytotoxicity of the methanol extract of $C$. gileadensis leaves and its fractions was evaluated using Vero and HEp-2 cells by determining the $\mathrm{CC}_{50}(\triangleright$ Table 1$)$. Results revealed no significant difference among the extracts with regard to the cytotoxicity against the 2 cell lines. After liquid-liquid extraction, the low-polarity fraction (dichloromethane) demonstrated high cytotoxicity as its $\mathrm{CC}_{50}$ highly decreased, while the polar fraction (methanol) demonstrated less cytotoxicity as its $\mathrm{CC}_{50}$ substantially increased.

The $\mathrm{IC}_{50}$ and $\mathrm{SI}$ of the methanol extract of $C$. gileadensis leaves against the enveloped viruses (HSV-2 and RSV-B) was approximately $20 \mu \mathrm{g} / \mathrm{mL}$ and > 10 ( $\triangleright$ Table 1 ). This extract demonstrated no activity against the nonenveloped viruses (CVB-3 and ADV-5).

After separation by liquid-liquid extraction, only the methanol fraction demonstrated activity with reduction in $\mathrm{IC}_{50}$ to $10 \mu \mathrm{g} / \mathrm{mL}$. The decrease in $\mathrm{IC}_{50}$ with an increase in $\mathrm{CC}_{50}$ strongly improved $\mathrm{SI}$ by approximately 10-fold (>100) against both HSV-2 and RSV-B ( Table 1).

The methanol extract of $C$. gileadensis leaves demonstrated a virucidal activity against both HSV-2 and RSV-B by complete inhibition of virus mediated by direct contact for $2 \mathrm{~h}$ at a concentration of $10 \times \mathrm{IC}_{50}(\triangleright$ Fig. 1). Moreover, less activity was observed during the viral adsorption, which can be explained by direct contact with the extract during the steps involving recognition and binding to specific host cell receptors.

The virucidal effect increased with contact time as shown in - Fig. 2. At a concentration of $10 \times \mathrm{IC}_{50}$, the methanol extract of C. gileadensis leaves completely inhibited enveloped viruses after $1 \mathrm{~h}$ of contact. The $\mathrm{VC}_{50}$, which represents the extract concentration required to induce $50 \%$ viral inhibition after $2 \mathrm{~h}$ of contact with the virus, was 15.12 (13.16-17.08) and 13.92 (10.8516.23) $\mu \mathrm{g} / \mathrm{mL}$ for HSV-2 and RSV-B, respectively. $V C_{50}$ decreased compared with $I C_{50}$, providing a Slv of 15.80 and 17.17 , respectively. The increase in $\mathrm{SI}$ indicated that the active extract was more effective when it was in direct contact with the virus (virucidal effect). Conversely, the methanol extract of $C$. gileadensis leaves showed preventive (before virus infection) or curative (after virus infection) antiviral effects.

The separation of the methanol extract of $C$. gileadensis leaves using TLC and the mobile phase, as described in the Material and Methods section, showed only 1 band with the following characteristics: red color under white light, blue color under UV light, and an RF $=0.18$. The dried fraction $(11.6 \mathrm{mg}$ ) comprised $6.63 \%$ of the active fraction. A second separation of this band using TLC, using the same mobile phase system with changes in the proportion of solvents, revealed no impurities.

The dried active fraction was dissolved in $500 \mu \mathrm{L}$ of $75 \%$ ethanol and subjected to HPLC-DAD-ESI-MS/MS. - Fig. 3 shows the UV profile ( $\vee$ Fig. $\mathbf{3 a}$ ) and total ion chromatogram registered in the positive-ionization mode ( $\vee$ Fig. $\mathbf{3 b}$ ). The HPLC profile showed 2 peaks: the one eluting at a retention time (Rt) of 18.62 min was the most abundant. This compound demonstrated the pseudomolecular ion at $\mathrm{m} / \mathrm{z} 313[\mathrm{M}+\mathrm{H}]^{+}$, which fragmented leading to a base peak at $\mathrm{m} / \mathrm{z} 109$ due to the steroid ring-A and a secondary ion at $m / z 97$. This fragmentation pattern led to the putative identification of guggulsterone ( $\triangleright$ Fig. 4 ) by comparing the data 
- Table 1 Cytotoxicity and antiviral activity of C. gileadensis leaves methanol extract and its fractions.

\begin{tabular}{|c|c|c|c|c|c|c|c|c|c|c|}
\hline \multirow[t]{2}{*}{ Extracts } & \multicolumn{2}{|l|}{$\mathrm{CC}_{50}(\mu \mathrm{g} / \mathrm{mL})$} & \multicolumn{4}{|l|}{$1 C_{50}(\mu \mathrm{g} / \mathrm{mL})$} & \multicolumn{4}{|l|}{$\mathrm{SI}=\mathrm{CC}_{50} / \mathrm{IC} \mathrm{C}_{50}$} \\
\hline & Vero cells & Hep-2 cells & HSV-2 & RSV-B & CVB-3 & ADV-5 & HSV-2 & RSV-B & CVB-3 & ADV-5 \\
\hline $\begin{array}{l}\text { Methanol } \\
\text { extract }\end{array}$ & $\begin{array}{l}239 \\
(261.11-216.89)\end{array}$ & $\begin{array}{l}264 \\
(290.85- \\
234.15)\end{array}$ & $\begin{array}{l}21.35 \\
(23.12-19.58)\end{array}$ & $\begin{array}{l}23.31 \\
(25.54-21.08)\end{array}$ & NA & NA & $\begin{array}{l}11.19 \\
(11.84-10.54)\end{array}$ & $\begin{array}{l}10.25 \\
(21.47-9.57)\end{array}$ & - & - \\
\hline $\begin{array}{l}\text { Hexane } \\
\text { fraction }\end{array}$ & $\begin{array}{l}208.33 \\
(225.39-190.94)\end{array}$ & $\begin{array}{l}183.33 \\
(203.02- \\
163.64)\end{array}$ & NA & NA & NA & NA & - & - & - & - \\
\hline $\begin{array}{l}\text { Dichloro- } \\
\text { methane } \\
\text { fraction }\end{array}$ & $\begin{array}{l}74.67 \\
(82.88-66.46)\end{array}$ & $\begin{array}{l}66.50 \\
(75.58-56.92)\end{array}$ & NA & NA & NA & NA & - & - & - & - \\
\hline $\begin{array}{l}\text { Methanol } \\
\text { fraction }\end{array}$ & $\begin{array}{l}1320 \\
(1463-1177)\end{array}$ & $\begin{array}{l}1512 \\
(1638-1386)\end{array}$ & $\begin{array}{l}10.41 \\
(11.37-9.45)\end{array}$ & $\begin{array}{l}11.26 \\
(11.69-10.83)\end{array}$ & NA & NA & $\begin{array}{l}126.80 \\
(131.61- \\
121.99)\end{array}$ & $\begin{array}{l}117.23 \\
(125.67- \\
108.79)\end{array}$ & - & - \\
\hline
\end{tabular}

$\mathrm{CC}_{50}$ : cytotoxic concentration $50 \%$; IC 50 : inhibitory concentration $50 \%$; SI: selectivity index; HSV-2 and RSV-B were grown on Vero cells, CVB-3 and ADV-5 on Hep- 2 cells. $\mathrm{CC}_{50}$ and $\mathrm{IC}_{50}$ values are expressed as mean ( $95 \%$ confidence interval) of 3 independent experiments. NA: not active.

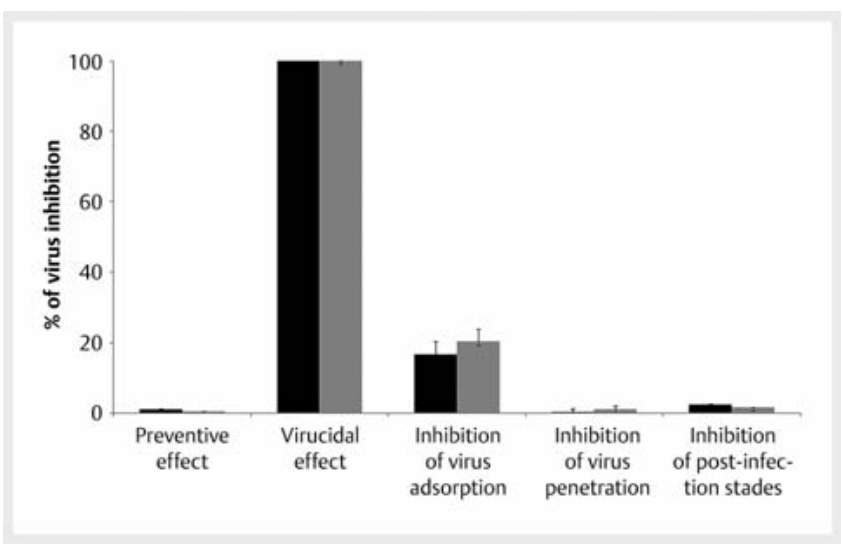

- Fig. 1 The mechanism underlying anti-HSV-2 and RSV-B activity of the methanol extract of $C$. gileadensis leaves. Sample concentration $=10 \times I C_{50}$. Black color: HSV-2. Gray color: RSV-B. Data represent the percentage of virus inhibition by comparing with virus control and are expressed as mean (95\% confidence interval) of 3 independent experiments.

obtained in this investigation with those reported in the literature [16]. The peak eluting at a Rt of 16.21 min provided a pseudomolecular ion at $\mathrm{m} / \mathrm{z} 313$ as well. As the registered signal in the MS spectrum was too weak for fragmentation, we hypothesized that this signal corresponded to another guggulsterone isomer. Therefore, based on the elution order, we considered that the Eisomer corresponded to the less retained compound. The chemical structured of the E- and Z-isomers of guggulsterone are illustrated in $>$ Fig. $\mathbf{5}$.

\section{Discussion}

This is the first report describing the antiviral effect of $C$. gileadensis. The methanol extract of leaves demonstrated this activity and appeared to target enveloped viruses (HSV-2 and RSV-B). This ac-

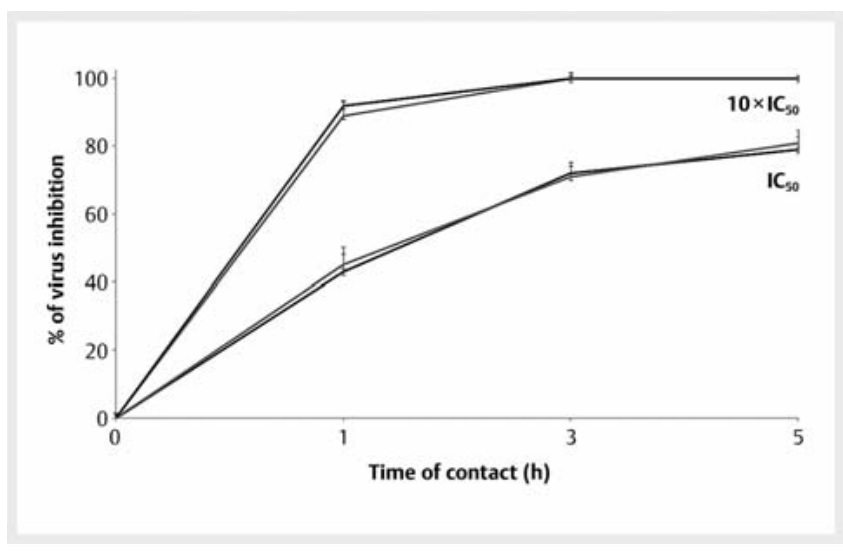

- Fig. 2 The effect of time course on HSV-2 and RSV-B inhibition by direct contact with the methanol extract of $C$. gileadensis leaves. Sample concentrations $=10 \times \mathrm{IC}_{50}$ and $\mathrm{IC}_{50}$. Black color: HSV-2. Gray color: RSV-B. Data represent the percentage of virus inhibition by comparing with virus control and are expressed as mean $(95 \%$ confidence interval) of 3 independent experiments.

tivity was clearly identified to be virucidal in nature, probably owing to the interaction of the active compound with receptor proteins present on the envelope, which could inhibit the ability of these viruses to bind to specific cell receptors, thus rendering them incapable of infecting host cells.

Studies have also reported the antiviral activity of other members of the genus Commiphora. For example, the crude extract of Commiphora swynnertonii Burtt, exhibits a strong antiviral activity against Newcastle disease virus [17]. Moreover, the methanol extracts of C. molmol, Commiphora parvifolia Engl., and Commiphora erythraea Engl. have been reported to have activities against hepatitis C [18], herpes virus type 1 [19], and parainfluenza type 3 virus [20], respectively. The compounds responsible for these activities appear to be terpenoids as the main chemical constituents of the methanol of C. parvifolia are triterpenoids [19], while 
RT: $0.00-30.00$
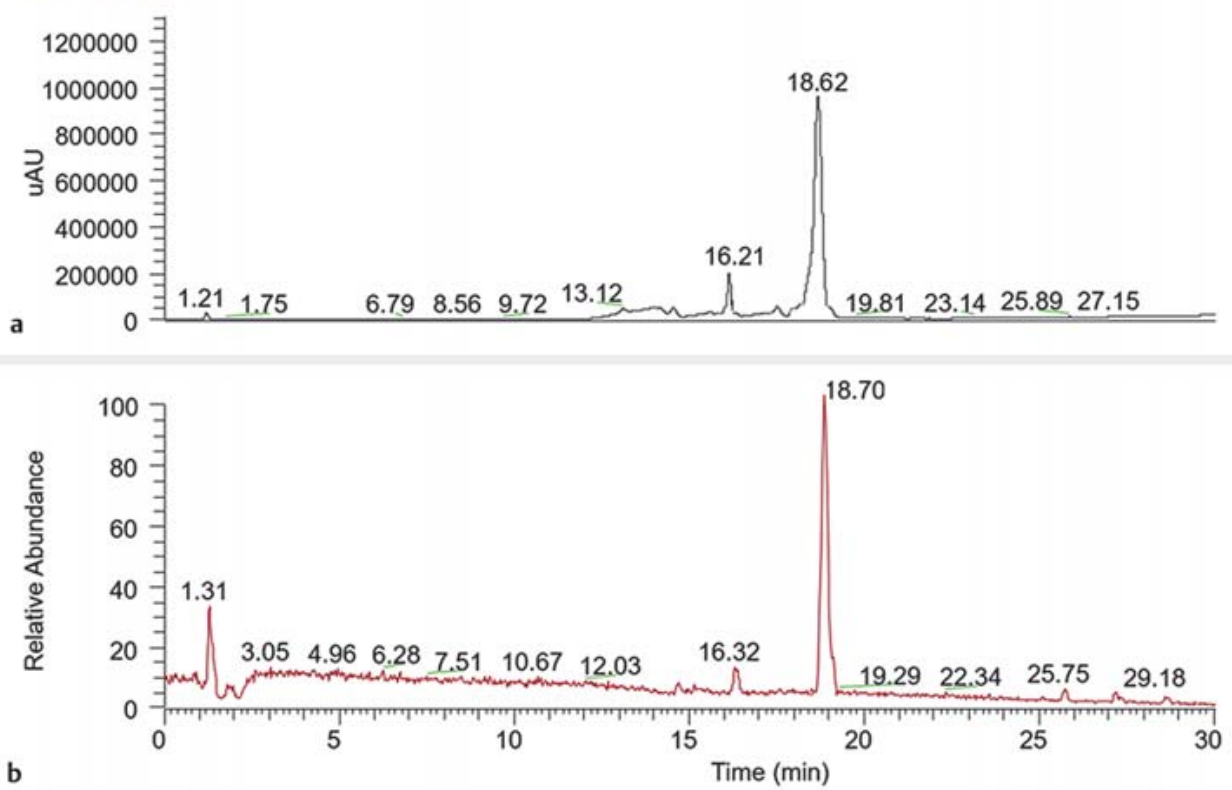

- Fig. 3 UV profile registered at $254 \mathrm{~nm}$ (a) and total ion chromatogram (TIC) of active fraction (b)

RT: 18.71 AV: 1 NL: 3.94E4

F: ITMS + c ESI Full ms2 313.42 [60.00-2000.00]

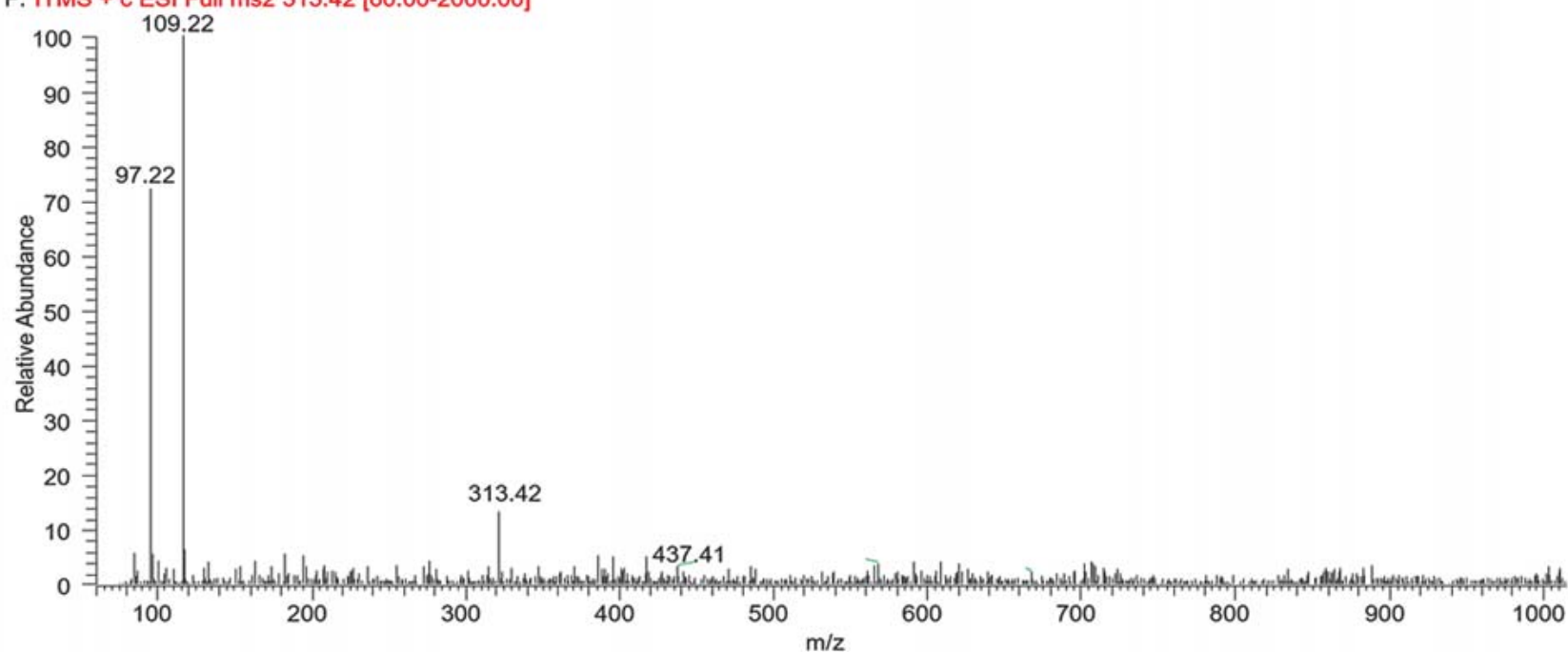

- Fig. 4 MS/MS spectrum of guggulsterone registered in positive ionization mode.

the active fractions of the methanol extract of $C$. erythraea are furanosesquiterpenoids [17].

The active compound responsible for the antiviral activity of C. gileadensis was isolated using bio-guided assays from the methanol fraction extracted using liquid-liquid separation from the methanol extract of leaves. The results of the HPLC-DADESI-MS/MS analysis indicated the putative presence of the E- and
Z-isomers of guggulsterone [4,17(20)-pregnadiene-3,16-dione]. These compounds have been previously reported in other species of Commiphora, such as Commiphora mukul Engl. and Commiphora wightii (Arn.) and always in resins [21,22]; therefore, this study is the first to report the putative identification of guggulsterone isomers in C. gileadensis leaves. 

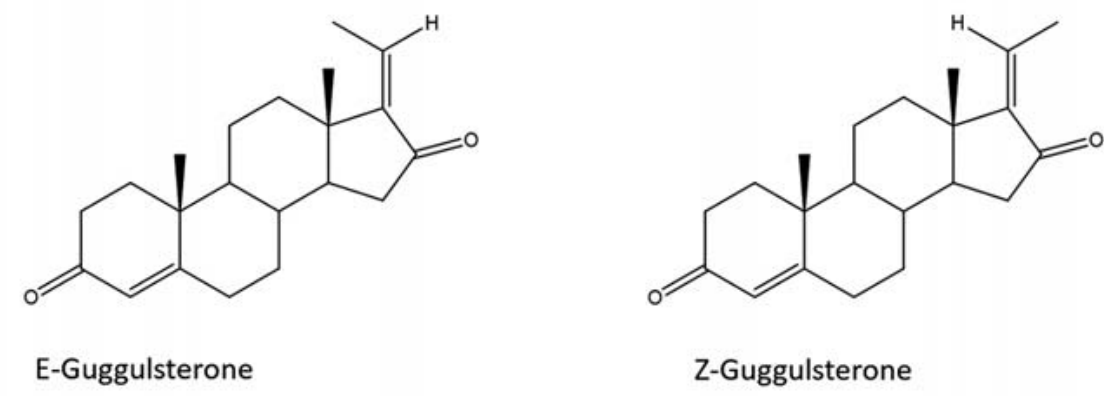

- Fig. 5 Chemical structure of E- and Z-guggulsterone.

Guggulsterone modulates cholesterol and triglyceride levels in serum and inhibits cholesterol synthesis in the liver [23-26]. Moreover, it was discovered as an antagonist of the farnesoid $X$ receptor, which is the bile acid receptor $[26,27]$ that is implied in the downregulation of the bile salt export pump [28, 29]. Consequently, guggulsterone has been used for treating hyperlipidemia and obesity. In addition to antagonizing farnesoid $\mathrm{X}$ receptor, guggulsterone modulates the activity of other steroid receptors, such as estrogen receptor alpha, progesterone receptor, and pregnane $X$ receptor $[29,30]$. Moreover, it inhibits the development of tumor cells with no considerable signs of toxicity on normal cells through the suppression of transcription factor activation, especially the NF- $K B$ [31] that is implicated in the proliferation and growth of malignant cells [32-34]. NF- $k B$ is also involved in the regulation of various factors associated with inflammation, such as cytokines, chemokines, inflammation-associated fibroblasts, and cell-adhesion molecules [35, 36]. Thus, guggulsterone was shown to exert a potent anti-inflammatory effect. Conversely, it has been found to be orally active in rats with a good pharmacokinetic profile with a bioavailability of $>40 \%$ and a half-life of approximately $10 \mathrm{~h} \mathrm{[37].}$

In summary, the present study demonstrated, for the first time, the antiviral activity of guggulsterone, which is the active compound isolated from C. gileadensis leaves; moreover, it highlighted the diversity of the biological activities of guggulsterone, such as anti-tumor, anti-inflammatory, and anti-lipid activities. This molecule exhibited a virucidal effect probably due to interaction with specific receptors of the enveloped viruses. However, further experiments are required to explain the mechanism of this interaction as well as to determine the nature of target receptors.

\section{Materials and Methods}

\section{Plant material and extract preparation}

C. gileadensis leaves were collected from Bader province, El Medina El Mounaoura (2428' 07" North-39³6' 39" East), the Kingdom of Saudi Arabia. The identity of this plant was confirmed by Prof. Abderrazak Smaoui (Laboratory of Extremophile Plants, Center of Biotechnology of Borj Cedria, Tunisia); moreover, a voucher specimen was deposited at the herbarium of this Center (registra- tion number: CG-KSA-CBBC-24/11/17). The leaves were lyophilized and ground. Subsequently, $5 \mathrm{~g}$ of powder was macerated with $50 \mathrm{~mL}$ of methanol for $24 \mathrm{~h}$. The extract obtained was filtered and subjected to sequential liquid-liquid separation using hexane and dichloromethane $(1: 1, v / v)$. Solvents were removed under vacuum by rotary evaporation, and the dried fractions (the hexane, dichloromethane and methanol fractions) were dissolved in $75 \%$ ethanol to obtain a final concentration of $50 \mathrm{mg} / \mathrm{mL}$ each.

\section{Cells and viruses}

The Vero and HEp-2 cell line were cultured in DMEM supplemented with $5 \%$ fetal FBS and maintained in DMEM with $2 \%$ FBS. HSV-2 and RSV-B were grown on Vero cells and CVB-3 and ADV-5 on HEp-2 cells. The Vero cell line was graciously provided by $\mathrm{Pr}$. Hela KALLEL (Laboratory of Laboratory of Molecular Microbiology, Vaccinology and Biotechnological Development, Pasteur Institute of Tunis, Tunisia); the clinical isolate of HSV-2 was provided by Mrs. Ahlem BEN YAHIA (Laboratory of Clinical Virology, Pasteur Institute of Tunis, Tunisia) and the HEp-2 cell line and the clinical isolates of CVB-3 and ADV-5 were provided by Dr. Hela JAIDANE and Dr. Khira ZDIRI (Laboratory of Transmissible Diseases, Faculty of Pharmacy of Monastir, Tunisia). The titration of HSV-2 and RSV-B was performed using the plaque assay [38] and that of CVB-3 and ADV-5 was performed using the endpoint dilution method [39].

\section{Cytotoxicity assay}

A 2-fold serial dilution of the sample starting from $3.33 \mathrm{mg} / \mathrm{mL}$ was added to semi-confluent cells in 96-well tissue culture plates. After $72 \mathrm{~h}$ of incubation, cells were trypsinized to obtain a singlecell suspension, followed by the addition of trypan blue solution $(10 \%, v / v)$. Living cells were counted as compared to untreated cells (cell control). The sample concentration that was able to reduce $50 \%$ of cell viability $\left(C_{50}\right)$ was determined using linear regression analysis based on data obtained from a from dose-response curve.

\section{Antiviral activity assay}

The anti-HSV-2 and anti-RSV-B assays were performed in 35-mm dishes using the plaque assay [40], while the anti-CVB-3 and antiADV-5 assays conducted in 96-well tissue culture plates using the MTT method [41] with some modifications in both the methods. 
A serial 2-fold dilution of sample starting from $\mathrm{CC}_{50} / 2$ was incubated with a viral culture (200 plaque forming unit for HSV-2 and RSV-B and 50 tissue culture infective doses for CVB-3 and ADV-5) for $1 \mathrm{~h}$ on confluent monolayer cells. After $48 \mathrm{~h}$ of incubation, the percentage of virus inhibition by the samples was evaluated compared with that by the untreated viruses (virus control). $I C_{50}$, defined as the concentration of sample that is able to reduce $50 \%$ cell infectivity, was determined by linear regression analysis using data from a dose-response curve. Antiviral activity was evaluated by determining $\mathrm{SI}$ calculated by the ratio of $\mathrm{CC}_{50}$ to $\mathrm{IC}_{50}$. The extract was estimated to have activity when $\mathrm{SI}$ was $>10$.

\section{Preventive effect assay}

The active fraction $\left(10 \times \mathrm{IC}_{50}\right)$ was incubated on confluent monolayer cells for $2 \mathrm{~h}$ at $37^{\circ} \mathrm{C}$. Then cells were washed twice with PBS to eliminate free compounds; subsequently, the viral culture (at the same titles used in the antiviral activity assay) was inoculated on cells for $1 \mathrm{~h}$. Cells were then washed with PBS to eliminate unadsorbed viruses, followed by culture in DMEM. After $48 \mathrm{~h}$ of incubation at $37^{\circ} \mathrm{C}$, the percentage of viral inhibition was calculated compared with incubation in virus control, as previously described.

\section{Virucidal assay}

The active fraction $\left(10 \times \mathrm{IC}_{50}\right)$ and viral culture (100 times the title used in the antiviral activity assay) were mixed and incubated for $2 \mathrm{~h}$ at $37^{\circ} \mathrm{C}$. The mixture was diluted 100 -fold to eliminate the effect of the extract on virus replication and then added to confluent monolayer cells. After $48 \mathrm{~h}$ of incubation at $37^{\circ} \mathrm{C}$, the percentage of viral inhibition was calculated by comparing with virus control, as previously described.

\section{Dose-response virucidal assay}

The dose-response virucidal assay was performed with a 2-fold serial dilution of active fraction starting from $10 \times \mathrm{IC}_{50}$. After $48 \mathrm{~h}$ of incubation at $37^{\circ} \mathrm{C}$, the percentage of viral inhibition following treatment with each dilution was calculated by comparing with virus control, as previously described. $V C_{50}$, defined as the sample concentration that reduces $50 \%$ of cell infectivity after direct contact with virus, was determined by linear regression analysis using data obtained from a dose-response curve. Virucidal activity was evaluated by determining the Slv calculated using $\mathrm{CC}_{50} / \mathrm{VC}_{50}$.

\section{Time-course virucidal assay}

The time-course virucidal assay was performed at different contact times $(0,1,3$, and $5 \mathrm{~h})$ of active fractions (concentrations, $10 \times I C_{50}$ and $I C_{50}$ ) with virus. After $48 \mathrm{~h}$ of incubation at $37^{\circ} \mathrm{C}$, the percentage of viral inhibition was determined by comparing it with virus control.

\section{Virus adsorption assay}

The active fraction $\left(10 \times \mathrm{IC}_{50}\right)$ and viral culture (at same titles used in the antiviral activity assay) were incubated on confluent monolayer cells at $37^{\circ} \mathrm{C}$. After $1 \mathrm{~h}$ of incubation, cells were washed with PBS to remove unadsorbed viruses and free active compounds, followed by exposure to DMEM. After $48 \mathrm{~h}$ of incubation at $37^{\circ} \mathrm{C}$, the percentage of viral inhibition was calculated by comparing with virus control, as described previously.

\section{Virus penetration assay}

Viral culture (at same titles used in the antiviral activity assay) was incubated on confluent monolayer cells at $4^{\circ} \mathrm{C}$. After $1 \mathrm{~h}$, cells were washed with PBS to remove unadsorbed viruses; subsequently, they were treated with active fraction $\left(10 \times \mathrm{IC}_{50}\right)$ for $1 \mathrm{~h}$ at $37^{\circ} \mathrm{C}$. Then cells were washed with PBS to remove free compounds and treated with citrate buffer $(40 \mathrm{mM}$ citric acid, $10 \mathrm{mM}$ $\mathrm{KCl}$, and $135 \mathrm{mM} \mathrm{NaCl} ; \mathrm{pH}=3$ ) for 1 min to inactivate adsorbed viruses. After removing citrate buffer, cells were exposed to DMEM. After $48 \mathrm{~h}$ of incubation, the percentage of viral inhibition was calculated by comparing with virus control, as described previously.

\section{Post-infection assay}

Viral culture (at same titles used in the antiviral activity assay) was incubated on confluent monolayer cells for $1 \mathrm{~h}$ at $37^{\circ} \mathrm{C}$. Subsequently, the viral culture was removed by washing of cells with PBS to remove unadsorbed viruses. Then the cells were treated with the active fraction (concentration, $10 \times \mathrm{IC}_{50}$ ). After $6 \mathrm{~h}$ of incubation at $37^{\circ} \mathrm{C}$, cells were washed with PBS to remove free compounds and then exposed to DMEM. After $48 \mathrm{~h}$ of incubation, the percentage of viral inhibition was calculated by comparing with virus control, as described previously.

\section{Isolation of the active compound by TLC}

For the isolation of the antiviral compound, the active fraction was subjected to TLC. A total of $175 \mathrm{mg}$ of active extracts was placed on a pre-coated silica gel $60 \mathrm{~F} 254$ glass plate $(20 \times 20 \mathrm{~cm}$; Glass Backed TLC Extra Hard Layer $60 \AA$ ) and was subjected to separation using hexane/ethyl acetate/methanol at a ratio of $3: 3: 1$. After separation, the plate was allowed to dry at room temperature and observed under UV light $(254 \mathrm{~nm})$. The bands observed under UV light were scraped off and dissolved in $75 \%$ ethanol under agitation for $15 \mathrm{~min}$. The obtained fractions were filtrated, dried, weighed, dissolved in $75 \%$ ethanol to obtain a final concentration of $10 \mathrm{mg} / \mathrm{mL}$ final, and evaluated for their antiviral activities. The active fraction was subjected again to TLC under similar conditions to verify its purity.

\section{Identification of the active compound by HPLC-DAD-ESI-MSn}

The analyses were performed using a Thermo Scientific LCQ FLEET system consisting of LCQ FLEET ion trap mass spectrometer, Surveyor MS Pump/Autosampler/PDA Detector (Thermo Fisher Scientific) through an ESI source. A Gemini C18 110A analytical column $(150 \times 2.00 \mathrm{~mm}$ i. d., $5 \mu \mathrm{m})$ with pre-column (Phenomenex) was used for the separation. The mobile phase consisted of formic acid $0.1 \%$ in water (solvent $A$ ) and methanol (solvent $B$ ) at $0.3 \mathrm{~mL}$ / min (injected volume $10 \mu \mathrm{L}$ ). A linear solvent gradient used was as follows: from $15 \%$ B to $100 \%$ B in 30 min, with a final plateau of $3 \mathrm{~min}$ at $100 \% \mathrm{~B}$. The ion trap operated in data-dependent, full scan (60-2000 m/z), and $\mathrm{MS}^{n}$ mode to obtain fragment ions $\mathrm{m} / \mathrm{z}$ with a collision energy of $35 \%$ and an isolation width of $3 \mathrm{~m} / \mathrm{z}$. The positive parameters of the ion mode ESI source have been op- 
timized to an ionization voltage of $5.0 \mathrm{kV}$, a capillary temperature of $300^{\circ} \mathrm{C}$, a capillary voltage of $33 \mathrm{~V}$, a sheath gas flow rate of 30 arbitrary units (AU), and an auxiliary gas flow rate of $10 \mathrm{AU}$.

\section{Statistical analysis}

All experiments were conducted in triplicate; statistical values are expressed as mean ( $95 \%$ confidence interval).

\section{Acknowledgements}

The authors are grateful to Pr. Hela Kallel (Laboratory of Laboratory of Molecular Microbiology, Vaccinology and Biotechnological Development, Pasteur Institute of Tunis, Tunisia)) for providing the Vero cell line, Mrs Ahlem Ben Yahia (Laboratory of Clinical Virology, Pasteur Institute of Tunis, Tunisia) for providing the clinical isolate of HSV-2, Dr. Hela Jaidane and Dr. Khira Zdiri (Laboratory of Transmissible Diseases, Faculty of Pharmacy of Monastir, Tunisia) for providing the HEp-2 cell line, and the clinical isolates of CVB-3 and ADV-5, Pr. Abderrazak Smaoui (Laboratory of Extremophile Plants, Center of Biotechnology of Borj Cedria, Tunisia) for the identification of the plant. The authors would like to thank Enago (www.enago.com) for the English language review.

\section{Conflict of Interest}

The authors declare that they have no conflict of interest.

\section{References}

[1] Chaudhary SA, Al-Jowaid AA. Vegetation of the Kingdom of Saudi Arabia. Riyadh: National Agriculture \& Water Research Center; 1999

[2] Hepper FN, Friis I. The Plants of Pehr Forsskal's Flora Aegyptiaco Arabiea. Kew: Royal Botanic Gardens; 1994: 1761-1763

[3] Miller AG, Morris M. Plants of Dhofar: the southern Region of Oman, traditional, economic and medicinal Uses. Oman: Office of the Adviser for Conservation of the Environment, Diwan of Royal Court Sultanate of Oman; 1988

[4] Migahid AM. Flora of Saudi Arabia, vol. 2. Riyadh: Riyadh University Publications; 1978: 647

[5] Al-Aklabi A, Al-Khulaidi AW, Hussain A, Al-Sagheer N. Main vegetation types and plant species diversity along an altitudinal gradient of Al Baha region, Saudi Arabia. Saudi J Biol Sci 2016; 23: 687-697

[6] Roweha A. Al-Tadawi Bel-A'ashab (Plant Therapy). Beirut: Al-Andalus Press; 1983: 170-172

[7] Al-Howiriny T, Al-Sohaibani M, Al-Said M, El-Tahir K, Rafatullah S. Hepatoprotective properties of Commiphora opobalsamum ("Balessan"), a traditional medicinal plant of Saudi Arabia. Drugs Exp Clin Res 2004; 30: 213-220

[8] Al-Yahya MA, Al-Meshal IAR, Mossa JS, Al-Badr AA, Tariq M. Saudi Plants: Phytochemical and Biological Approach. KASCT No 39. Riyadh: King Saud University Press; 1990

[9] Abdul-Ghani AS, Amin R. Effect of aqueous extract of Commiphora opobalsamum on blood pressure and heart rate in rats. J Ethnopharmacol 1997; 57: 219-222

[10] Al-Howiriny T, Al-Sohaibani M, Al-Said M, Al-Yahya M, El-Tahir K, Rafatullah S. Effect of Commiphora opobalsamum (L.) Engl. (Balessan) on experimental gastric ulcers and secretion in rats. J Ethnopharmacol 2005; 98: 287-294

[11] Wineman E, Douglas I, Wineman V, Sharova K, Jaspars M, Meshner S, Bentwich Z, Cohen G, Shtevi A. Commiphora gileadensis sap extract induces cell cycle-dependent death in immortalized keratinocytes and human dermoid carcinoma cells. J Herb Med 2015; 5: 199-206
[12] Abbas FA, Al-Massarany SM, Khan S, Al-Howiriny TA, Mossa JS, Abourashed EA. Phytochemical and biological studies on Saudi Commiphora opobalsamum L. Nat Prod Res 2007; 21: 383-391

[13] Orchard A, Sandasi M, Kamatou G, Viljoen A, van Vuuren SF. The in vitro antimicrobial activity and chemometric modelling of 59 commercial essential oils against pathogens of dermatological relevance. Chem Biodivers 2017; 14: e1600218

[14] Lee K, Lee JH, Kim SI, Cho MH, Lee J. Anti-biofilm, anti-hemolysis, and anti-virulence activities of black pepper, cananga, myrrh oils, and nerolidol against Staphylococcus aureus. Appl Microbiol Biotechnol 2014; 98: 9447-9457

[15] Al-Sieni Al. The antibacterial activity of traditionally used Salvadora persica L.(miswak) and Commiphora gileadensis (palsam) in Saudi Arabia. Afr J Tradit Complement Altern Med 2014; 11: 23-27

[16] Bhatta RS, Kumar D, Chhonker YS, Jain GK. Simultaneous estimation of $\mathrm{E}$ - and Z-isomers of guggulsterone in rabbit plasma using liquid chromatography tandem mass spectrometry and its application to pharmacokinetic study. Biomed Chromatogr 2011; 25: 1054-1060

[17] Bakari GG, Max RA, Mdegela RH, Phiri EC, Mtambo MM. Antiviral activity of crude extracts from Commiphora swynnertonii against Newcastle disease virus in ovo. Trop Anim Health Prod 2012; 44: 1389-1393

[18] Hussein G, Miyashiro H, Nakamura N, Hattori M, Kakiuchi N, Shimotohno K. Inhibitory effects of Sudanese medicinal plant extracts on hepatitis $C$ virus (HCV) protease. Phytother Res 2000; 14: 510-516

[19] Mothana RA, Mentel R, Reiss C, Lindequist U. Phytochemical screening and antiviral activity of some medicinal plants from the island Soqotra. Phytother Res 2006; 20: 298-302

[20] Cenci E, Messina F, Rossi E, Epifano F, Marcotullio MC. Antiviral furanosesquiterpenes from Commiphora erythraea. Nat Prod Commun 2012; 7: 143-144

[21] Haque I, Kumar M, Mukhopadhyay K. A rapid and simple UPLC-MS-MS based simultaneous determination of the medicinally important $\mathrm{E}$ - and Z-guggulsterone from oleogum-resins of naturally occurring Commiphora wightii plants. Chromatographia 2009; 70: 1613-1619

[22] Musharraf SG, Iqbal N, Gulzar U, Ali A, Choudhary MI, Atta-Ur-Rahman. Effective separation and analysis of E- and Z-guggulsterones in Commiphora mukul resin, guggulipid and their pharmaceutical product by high performance thin-layer chromatography-densitometric method. J Pharm Biomed Anal 2011; 56: 240-245

[23] Nityanand S, Srivastava JS, Asthana OP. Clinical trials with gugulipid. A new hypolipidaemic agent. J Assoc Physicians India 1989; 37: 323-328

[24] Singh RB, Niaz MA, Ghosh S. Hypolipidemic and antioxidant effects of Commiphora mukul as an adjunct to dietary therapy in patients with hypercholesterolemia. Cardiovasc Drugs Ther 1994; 8: 659-664

[25] Szapary PO, Wolfe ML, Bloedon LT, Cucchiara AJ, DerMarderosian AH, Cirigliano MD, Rader DJ. Guggulipid for the treatment of hypercholesterolemia: a randomized controlled trial. JAMA 2003; 290: 765-772

[26] Urizar NL, Liverman AB, Dodds DT, Silva FV, Ordentlich P, Yan Y, Gonzalez FJ, Heyman RA, Mangelsdorf DJ, Moore DD. A natural product that lowers cholesterol as an antagonist ligand for FXR. Science 2002; 296: 1703-1706

[27] Wu J, Xia C, Meier ], Li S, Hu X, Lala DS. The hypolipidemic natural product guggulsterone acts as an antagonist of the bile acid receptor. Mol Endocrinol 2002; 16: 1590-1597

[28] Cui J, Huang L, Zhao A, Lew JL, Yu J, Sahoo S, Meinke PT, Royo I, Peláez F, Wright SD. Guggulsterone is an farnesoid $X$ receptor antagonist in coactivator association assays but acts to enhance transcription of bile salt export pump. J Biol Chem 2003; 278: 10214-10220

[29] Owsley E, Chiang JY. Guggulsterone antagonizes farnesoid X receptor induction of bile salt export pump but activates pregnane $X$ receptor to inhibit cholesterol 7alpha-hydroxylase gene. Biochem Biophys Res Commun 2003; 304: 191-195 
[30] Burris TP, Montrose C, Houck KA, Osborne HE, Bocchinfuso WP, Yaden BC, Cheng CC, Zink RW, Barr RJ, Hepler CD, Krishnan V, Bullock HA, Burris LL, Galvin RJ, Bramlett K, Stayrook KR. The hypolipidemic natural product guggulsterone is a promiscuous steroid receptor ligand. Mol Pharmacol 2005; 67: 948-954

[31] Shishodia S, Aggarwal BB. Guggulsterone inhibits NF- $\kappa B$ and I $k B \alpha$ kinase activation, suppresses expression of anti-apoptotic gene products, and enhances apoptosis. J Biol Chem 2004; 279: 47148-47158

[32] Aggarwal BB. Nuclear factor- $\kappa$ B: the enemy within. Cancer Cell 2004; 6 : 203-208

[33] Beg AA, Baltimore D. An essential role for NF- $k B$ in preventing TNF- $\alpha$-induced cell death. Science 1996; 274: 782-784

[34] Van Antwerp DJ, Martin SJ, Kafri T, Green DR, Verma IM. Suppression of TNF- $\alpha$-induced apoptosis by NF- $\kappa B$. Science 1996; 274: 787-789

[35] Baeuerle PA, Henkel T. Function and activation of NF-kappaB in the immune system. Annu Rev Immunol 1994; 12: 141-179
[36] Lv N, Song MY, Kim EK, Park JW, Kwon KB, Park BH. Guggulsterone, a plant sterol, inhibits NF-KB activation and protects pancreatic $\beta$ cells from cytokine toxicity. Mol Cell Endocrinol 2008; 289: 49-59

[37] Verma N, Singh SK, Gupta RC. Pharmacokinetics of guggulsterone after intravenous and oral administration in rats. Pharma Pharmacol Commun 1999; 5: 349-354

[38] Sudo K, Konno K, Yokota T, Shigeta S. A sensitive assay system screening antiviral compounds against herpes simplex virus type 1 and type 2 . J Virol Methods 1994; 49: 169-178

[39] Reed L, Muench H. A simple method of estimating fifty pet cent endpoints. Am J Epidemiol 1938; 27: 493-497

[40] Hayashi K, Hayashi T, Morita N. Mechanism of action of the antiherpesvirus biflavone ginkgetin. Antimicrob Agents Chemother 1992; 36: 1890-1893

[41] Guo JP, Pang J, Wang XW, Shen ZQ, Jin M, Li JW. In vitro screening of traditionally used medicinal plants in China against enteroviruses. World J Gastroenterol 2006; 12: 4078-4081 